head turned to the right side. I'here were no trophic changes anywhere. On Dec. 18th the patient had recovered tone in the bladder and the sphincter, and respiration, both thoracic and abdominal, was good. On the 20th the bladder and the bowels could retain their contents much better and the patient could move his left leg fairly well. Sensation also was improved. By the 25 th there was a slight improvement in. the sensation of the left arm and the left leg was still improving. There were no other symptoms. The patient was convalescent on Jan. 1st, 1900, and was sent home to Netley. At this time motion in the left arm was improving daily and sensation was good.

Enteric fever has claimed another victim in Major C. P. Walker, K.A.M.C., who died in Natal, aged 40 years. I am glad to say that the last reports of Lieutenant W. Jagger, R.A.M.C., who is suffering from the same disease, are favourable.

To-day (Feb. 7th) the Spartan brought down from Durban 370 wounded officers and men who will be distributed amongst the various general hospitals. The Lismore Castlc is en route for Cape Town with 180 more. These are some of the 1020 wounded in General Warren's fights at Spion Kop, where, as you know, the killed, wounded, and missing amounted to the serious total of 1700 , by far the heaviest losses we have sustained in any operation up to date The enteric fever at Modder river and at Orange river is still very bad, as many as 70 cases being reported from the former place. The Kildonan Castle is leaving to-day for England with a large batch of sick and wounded and I hear that the outward transports have again dropped a great number of men for treatment in the Cape l'own hospitals. I suppose that this is unavoidable to a certain extent, but still I cannot help thinking that more care might be exercised in the medical examination of men destined for duty at the front before they leave England, as some ot these cases, notably cases of bernia, might easily hare been detected prior to embarkation. These patients take up badly wanted accommodation in the rarious hospitals, and in many cases they never get further than the wards, from whence they are sent home again, costing the country money that might well be expended in other directions.

The frightful mortality amongst officers in the recent engagement, there being no less than 32 killed, 66 wounded, and six missing, seems to the lay mind to point to unnecessary exposure on their part, or to the enemy's well-known sharpness in detecting them in spite of the various means taken to make their appearance as similar as possible to their men. You will have received a more detailed list long before this reaches you ; in fact, our last information regarding casualties was taken from a London paper. I have not had an opportunity of inspecting the new ambulance train yet, but from what $I$ hear it is very complete.

The Princess of Trales has left for Netley with sick and wounded. She will be followed by the Aroca, which leaves to-day.

Claremont, Feb. 7th.

\section{THE TREATMENT OF SOME FORMS OF APPENDICITIS AT PLOMBIERES WITHOUT OPERATION.}

By Skene Keith, M.B., C.M., F.R.C.S. EdiN.

THE account of one case will give a very good idea of in what the treatment of appendicitis at Plombières consists. The history of the case in question evidently dated back to an attack of peritonitis some 12 years ago, when the patient was 23 years of age. So far as the patient can remember she was confined to bed for at least two weeks. The abdominal pain was very severe. Complete recovery followed this attack, except that from that time there was a disinclination to go up many stairs, as this brought on a feeling of tiredness in the right side and thigh. Indeed, on one occasion after going up a number of stairs while sight-seeing abrcad, the patient was unable to sleep one night on account of the pain in the right side. In the autumn of 1895 she moved into a larger house, and although she felt the longer stairs a fatigue and went up and down as seldom as possible she was able to learn to bicycle in the spring of the following year and could go for from 20 to 30 miles in a day without setting up any of the pain in the side or in the thigh. In the beginning of 1896 she began to suffer from pain in the right side, and on examination the chief seat of the pain and tenderness was found to be midway between the umbilicus and the right anterior superior iliac spine. The bowels were attended to, some $\beta$ naphthol was ordered, and a belladonna plaster was put over the whole of the right side. This treatment was followed by marked improvement, but the patient broke down on a journey to Italy and had to remain in Paris. At this time there was no pain, she was simply tired out. For about a month after coming back from Paris she was perfectly well, but towards the end of May the pain returned. On examination the appendix could be felt with the greatest ease. It felt almost as thick as my thumb. I do not think that it was in reality anything like so large as this, for my experience has been, while operating, that the appendix is actually smaller than it feels from the outside. This has also been my experience with diseased ovaries and Fallopian tubes, and I consider that one has always to discount a considerable amount of the apparent size. The patient was kept as quiet as possible and the treatment which had before been successful was renewed. The very slightest irregularity of the bowels was invariably found to increase the pain. A courke of baths at Plombières was recommended, but the patient did not wish to waste her time by "going in for" a water-cure. Another physician was consulted and he independently advised a visit to the same place. The patient was undoubtedly of a gouty habit, and had there been no previous attack of peritonitis I would have diagnosed simply a gouty irritation of the appendix.

The patient went to Plombieres at the beginning of August, 1897. The treatment consisted in 21 baths, taken one every day. She lay for from 40 to 50 minutes covered to the neck in the water, at not less than $34^{\circ} \mathrm{C}$. and not more than $36^{\circ} \mathrm{C}$. After the first few baths and for the last 10 minutes of each succeeding one the douche Tiroli was used. This is simply a spray of warmer water coming out of a rose somewhere about an inch in diameter, which, passing through the water of the bath, is allowed to play against the affected part like a feather. This is a most important point. If it be used too strong it seems to do harm, as there is almost certain to be an attack of pain when the douche is improperly used in this way. After the bath the patient had to lie down in bed for half an hour. If a patient goes to sleep at this time there is said to be a headache in the afternoon. Before leaving the patient was told by the medical officer (Dr. Bottentuit) and the bath attendants that she would require to return twice more. This she firmly resolved she would not do, as the treatment was so simple that she had absolutely no faith in it. Possibly owing to not being very careful at first the pain went away slowly and there were many complaints that the treatment at Plombieres was nothing but "humbug." But by the beginning of the year 1898 the patient was quite well and was losing the habit of considering before going upstairs whether she really required to go. In the middle of June she suddenly broke down after bicycling about 12 miles and bad to drive home. Pain and tenderness at McBurney's point were again found, though the appendix itself could not be made out. A second visit was therefore made to Plombières in August, much to the triumph of the bath attendant. Exactly the same treatment was carried out at this second visit as at the first. It is now 14 months since the patient felt any discomfort in the region of the appendix. She has wicycled 30 miles at a time and she can go upstairs without giving it a thought. For the first time in her life she has had this winter an acute attack of gout in her foot and still the appendix is giving no trouble.

One case in particular, where I removed the appendix, contrasts very markedly with that which I have just narrated. The history was simply of one acute attack followed by rapid loss of health and strength, accompanied by pain in the right side. The patient was a medical man, and it was evident that he would soon have to stop work altogether. There was no difficulty in feeling the appendix, and at the operation one narrow band of adhesion was found which bent the appendix at an acute angle, and in this way had first caused congestion and then inflammation of the appendix. As in this case the cause was a mechanical one no course of baths or any general treatment could have been expected to do any permanent good. Fome years afterwards the patient told me that he had forgotten the 
illness before the operation and the illness at the time of the operation, but he said that the misery experienced while his strength was returning was a thing he could never forget.

Plombières does not seem to be sufficiently known to the medical profession. It is probably the best place in the world for the majority of cases of chronic diarrhoa, and of late years it is coming to be recognised as a place where many cases of appendicitis may be cured without operation. The cases which do best are probably those where the appendicitis is, in part at least, due to some general condition. Quite a considerable number of patients have been sent who have not been cured of their appendicitis by the removal of the appendix! Many people may not care to go to France for pleasure at the present time, but as the healing art does not require to pay attention to political matters a short account may be of interest. Indeed, the place seems to be so little known that a hospital surgeon who had himself suffered from appendicitis had never even heard of it.

This bathing station is situated in a valley 1400 feet above sea-level, on a short branch line of nine miles, midway between Nancy and Belfort, and can be reached either directly from Calais or via Paris. English ladies travelling in the restaurant train from Paris had better secure their seats in the restaurant car by sitting in them when the train is full. The villagers are conservative; they oppose every innovation and have so managed that the railway ends at Plombières and can apparently never be continued beyond it. To do this they had to take what $I$ am told was the finest part of the park which had been laid out by Napoleon III. at the time be had the new baths built. Napoleon's old bath-man is still in attendance, having put in 37 seasons without missing one day in all those years. One old woman over 80 years of age, who lives in the main street close to the old Roman bath, has never seen the railway or the new baths, though both are within onethird of a mile. She is, however, something of a character. The baths themselves are fairly goor and there is an abundance of both hot and cold water. Indeed, the water comes up so hot that it has to be taken to a reservoir up the hill to cool it before it can be used. At one of the older establishments, mostly used for rheumatism, one can go down and see the water bubbling up. The air there is so hot and steamy that it is somewhat difficult to penetrate to the lowest depths, and ladies should not go down when they have on any clothes which might spoil with damp.

The treatment for appendicitis appears to be what I have already described, with, in addition, the use of the douche ascendarte when there is constipation. One peculiarity of the donche Tiroli is that the water feels warm when directed against a healthy part of the body but not when it is playing against the affected spot. During the course of the 21 baths the patient is, as a general rule, depressed and miserable, though this seems to be less marked when the weather is warm. The great thing required is to be content to do nothing. Patients may apparently lie in bed, sit at the band or in the casino, and may drive, but must not exert themselves at all. For anyone who likes to be dull and doing nothing I can recommend Plombières, aluhough it is not the dullest of bathing stations. There is, however, one great objection to the place, and one which could be easily remedied. It is that no provision has apparently been made for provid. ing proper food for those suffering from disorders of the alimentary tract. The medical officers put the best face on it and say that the waters are so beneficial that the quality of the food does not matter, although the meat provided is notoriously so hard as to be almost uneatable. I have travelled much in France and do not expect to find French meat very tender, but it certainly was a surprise to find the meat which I got at Plombières - a place devoted in large part to the treatment of gastric and intestinal disorders. There are several hotels and many lodgings and in one of these hotels the food was very good indeed. Although a man could go alone it would be too dull for a lady without a companion. I do not mean to say that a lady could not go alone, but to send any lady ill to start with and feeling worse $a^{2}$ some part of the course would not be a very kindly act. It is not a very expensive place ; the ticket from London direct by Calais is $£ 412 s$.; no return tickets are issued. The rate at an hotel not attached to the new bathing establishment and within two minutes' walk of the baths per day and without wine is 10 francs and upwards. Baths and the douche
Tivoli cost under 5 francs or less at the other bathing establishments in the town. Some of them seemed to be almost as comfortable as the new baths and the arrange. ments for the supply of water are exactly the same. A man who could take his baths without a break could do the whole course from Jondon and back for about $£ 32$ including the medical officer's fees, "tips," and ordinary wine, but excluding the casino. The majority of ladies would not be able to get through a course quite so expeditiously, and a very pleasant way of utilising the break which usually occurs is by driving to Gerardmer and the Schlucht. Gerardmer is situated on the lake of the same name, over 2000 feet above the level of the sea. It is a very lovely spot and is said to be bracing; but it has the disadvantage of being very full in summer, too full, indeed, for comfort. From Gerardmer to the Schlucht, over 4000 feet high, is a drive of about three hours, through pine woorls and passing hills and lakes. The German hotel, much better situated than the French, is about one mile across the frontier, and the view from it embraces the whole of the $M$ ünster valley. The return drive to Gerardmer can be made, in part, alongside the lakes instead of high above them.

The bathing season does not begin till June 1st and finishes in the end of September, July and August being the two months when the village is full of visitors and when literally there is not an empty bedroom. During these two months it is very necessary to engage rooms before starting. The beginning and the end-especially the end-of the season are to be avoided. Even the band stops playing before the end of September, while the theatrical company leaves at about the beginning of the month.

In my experience the treatment at Plombières is very successful in cases of chronic diarrhoea, in constipation (though at first sight this may seem peculiar), in mucous colitis, and in appendicitis. The baths-and the treatment is practically limited to baths, though many people drink a small quantity of water before lunch and dinner-are recommended for various other conditions, especially for rhenmatism. Comparatively few English go to Plombières, though the numbers are said to be increasing.

\section{THE ROYAL COMMISSION ON THE METROPOLITAN WATER-SUPPLY. \\ (Continued from p. 565.)}

LORD LLANDAFF's Commissioners point out that before it is possible to determine whether purchase of the metropolitan water companies' undertakings is likely to be financially advantageous to the water consumers it is necessary to consider how the price to be paid will be fixed. They do not think it likely that the price can be settled by agreement In the year 1880 an attempt was made by Lord Beacons. field's Government to purchase the undertakings and the agreements arrived at were afterwards held by Sir William Harcourt's committee to be unsatisfactory, and since that date no serious attempt has been made to purchase by agreement. Many years ago negotiations which were entered into between the New River Company and the City of London had no result. The details were con fidential.

In the year 1896 Sir Arthur Arnold, who was then chairman of the London County Council, entered into some negotiations with the chairmen of the water companies. As the result of the conversations which be bad with them be came to the conclusion that some of the companies would be willing to sell their businesses on reasonable terms and that the purchase might be effected by agreement. The surviving chairmen of the companies through their counsel denied that the impression left on Sir Arthur Arnold's mind was wel founded and denied also that any approach to an agreement was made.

In the year 1890 a Select Committee of the House of Commons, which was presided over by Sir Matthew White Ridley, examined several Bills, amongst which was one promoted by certain London vestries and parishes, which proposed that a water trust should be formed for the acquisition of the companies' undertakings under the Land Clauses Act with certain modifications, and a Bill was also framed 